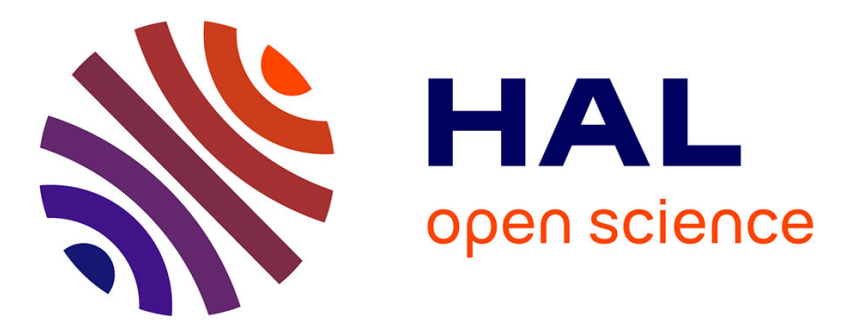

\title{
Ob' river discharge from TOPEX/Poseidon satellite altimetry (1992-2002)
}

\author{
A. Kouraev, E. A. Zakharova, O. Samain, N. Mognard-Campbell, A. Cazenave
}

\section{To cite this version:}

A. Kouraev, E. A. Zakharova, O. Samain, N. Mognard-Campbell, A. Cazenave. Ob' river discharge from TOPEX/Poseidon satellite altimetry (1992-2002). Remote Sensing of Environment, 2004, 93 (1-2), pp.238-245. 10.1016/j.rse.2004.07.007 . hal-00280276

\section{HAL Id: hal-00280276 https://hal.science/hal-00280276}

Submitted on 6 Apr 2020

HAL is a multi-disciplinary open access archive for the deposit and dissemination of scientific research documents, whether they are published or not. The documents may come from teaching and research institutions in France or abroad, or from public or private research centers.
L'archive ouverte pluridisciplinaire HAL, est destinée au dépôt et à la diffusion de documents scientifiques de niveau recherche, publiés ou non, émanant des établissements d'enseignement et de recherche français ou étrangers, des laboratoires publics ou privés. 


\title{
Ob’ river discharge from TOPEX/Poseidon satellite altimetry (1992-2002)
}

\author{
Alexei V. Kouraev ${ }^{\mathrm{a}, \mathrm{b}, *}$, Elena A. Zakharova ${ }^{\mathrm{b}}$, Olivier Samain ${ }^{\mathrm{c}}$, \\ Nelly M. Mognard ${ }^{\mathrm{a}}$, Anny Cazenave ${ }^{\mathrm{a}}$ \\ ${ }^{\mathrm{a}}$ Laboratoire d'Etudes en Géophysique et Océanographie Spatiales (LEGOS), Toulouse, France \\ ${ }^{\mathrm{b}}$ State Oceanography Institute, St. Petersburg Branch, St. Petersburg, Russia \\ ${ }^{\mathrm{c}}$ Météo-France, CNRM, Toulouse, France
}

\begin{abstract}
The paper discusses an application of the TOPEX/Poseidon (T/P) altimetry data to estimate the discharge of one of the largest Arctic rivers - the $\mathrm{Ob}$ ' river. We first discuss the methodology to select and retrieve the altimeter water levels during the various phases of the hydrological regime. Then we establish the relationships between the satellite-derived water levels and the in situ river discharge measurements at the Salekhard gauging station near the Ob' estuary. The comparison of in situ and satellite-derived estimations of the Ob' discharge at Salekhard shows that the T/P data can successfully be used for hydrological studies of this river. We address the problems affecting the accuracy of the discharge estimations from altimeter measurements, identify potential solutions and suggest how satellite altimetry data may benefit hydrological studies of Arctic rivers.
\end{abstract}

Keywords: Radar altimetry; Ob’ river level and discharge; TOPEX/Poseidon

\section{Introduction}

Rivers are an integral part of the global climate system, sensitive to its regional and global variations. and therefore a strong indicator of climate change. Global warming is expected to be the most significant with strong feedback on global climate in the arctic regions (IPCC, 2001). Climatic change will lead to potential increase in freshwater release into the Arctic Ocean, which in turn will affect thermohaline circulation, as well as ice and North Atlantic Deep Water (NADW) formation (Broecker, 1997; Rahmstorf, 1995). Peterson et al. (2002) have shown using in situ river monitoring data that the average annual discharge of freshwater from the largest Eurasian rivers to the Arctic Ocean has already increased by 7\% from 1936 to 1999 .

* Corresponding author. LEGOS, 18 Avenue Edouard Belin, 31401 Toulouse Cedex 9, France. Tel.: +33 561332902.

E-mail address: akou2@mail.ru (A.V. Kouraev).
In situ measurements of river discharge are rather sparse in the remote Arctic environments. Besides this, a general decline in the arctic hydrologic monitoring network has begun in the mid-1980s (Shiklomanov et al., 2002). These conditions make microwave satellite sensor measurements an essential complement to in situ observations, and in some cases, to serve as virtual gauging stations. Recently, it has been demonstrated that TOPEX/ Poseidon (T/P) altimetry could provide valuable information on water level variations of rivers, wetlands and floodplains with the precision of several tens of centimetres (Birkett, 1995, 1998; Bjerklie et al., 2003; de Olivera Campos et al., 2001; Maheu et al., 2003; Mercier, 2001).

Most of the altimeter-based studies on river streamflow have been performed in tropical or equatorial regions. Here we assess the applicability of satellite altimetry data for arctic rivers, where the presence of ice and snow perturbs the altimetric signal during a large portion of the year. One of the largest Eurasian rivers - the Ob' riverwas chosen in order to estimate the accuracy of the $T / P$ 
altimetric measurements of river level and discharge. We first discuss the methodology used to select and retrieve the altimeter water levels during the various phases of the $\mathrm{Ob}$ ' hydrological regime. Next, we establish relationships between satellite-derived water level and river discharge measurements at Salekhard gauging station near the $\mathrm{Ob}$ ' estuary. We consider a simplified relation between the water level $(H)$ and river discharge $(Q)$ without the use of detailed in situ information on hydraulic and morphological particularities of the chosen river section. This simplification is done in order to estimate the applicability of such an approach for conditions when such base information is not available. The calculated discharges are then compared with in situ measurements and an assessment of the accuracy of the altimeter discharge estimates is performed.

\section{The $\mathrm{Ob}^{\prime}$ river and its hydrological regime}

The $\mathrm{Ob}^{\prime}$ has the largest watershed of all Arctic rivers $\left(2,975,106 \mathrm{~km}^{2}\right)$ and is the third largest contributors of freshwater to the Arctic ocean (mean annual flow of 402 $\mathrm{km}^{3} /$ year) after the Yenisey and Lena rivers (Russia: river basins, 1999). The $\mathrm{Ob}$ ' length is $3,680 \mathrm{~km}$ from the confluence of Biya and Katun' rivers in the Altay mountain region to the $\mathrm{Ob}^{\prime}$ bay in the Kara sea. According to the hydrographic conditions and river regime, the $\mathrm{Ob}^{\prime}$ is usually divided into the three main parts (Fig. 1) - the Upper Ob' (from the confluence of Biya and Katun' up to the confluence of $\mathrm{Ob}$ ' and Tom'), the Middle $\mathrm{Ob}$ ' (from the Tom' mouth to the Irtysh mouth), and the lower Ob' (from the Irtysh mouth to the
Ob' bay). The object of our study is the lower Ob' near its confluence to the $\mathrm{Ob}$ ' bay.

The Ob' hydrographical network is characterised by a sharp asymmetry - most of the watershed area $(67 \%$ of the total area) is located on the left-bank. Another typical feature is the presence of areas of inner discharge (not providing inflow to the $\mathrm{Ob}^{\prime}$ river system), which cover $15 \%$ of the watershed area. A large part of the watershed is located within the West Siberian plain and the flat relief significantly affects the hydrographical network. In the region of the lower Irtysh and lower Ob', there are 70,000 water streams, $89 \%$ of them being less than $10 \mathrm{~km}$ long (Russia: river basins, 1999). The Ob' of the West Siberian plain is also characterised by large flooded areas, frequently described as the biggest world swamp. The region is abundant with lakes (over 450,000), mainly small lakes with surface area less than $1 \mathrm{~km}^{2}$ and depths of $2-5 \mathrm{~m}$.

The distribution of the river discharge in various parts of the $\mathrm{Ob}$ ' river system has complex patterns with long flood periods. The latitudinal extent of the $\mathrm{Ob}$ ' watershed (from $47^{\circ} \mathrm{N}$ to $68^{\circ} \mathrm{N}$ ) results in the gradual melting of snow during the spring and in a smooth temporal distribution of the discharge during the flooding period. The Ob' discharge starts to increase in April, when the flood wave begins to break the ice cover, and reaches maximal values in May-June. During this time, large areas of the $\mathrm{Ob}$ ' basin are flooded. The discharge then gradually decreases until July-August, and in SeptemberOctober an autumn low level period is observed. About $75-80 \%$ of the annual flow is observed during the open water period before the river gets covered by ice until the next spring.
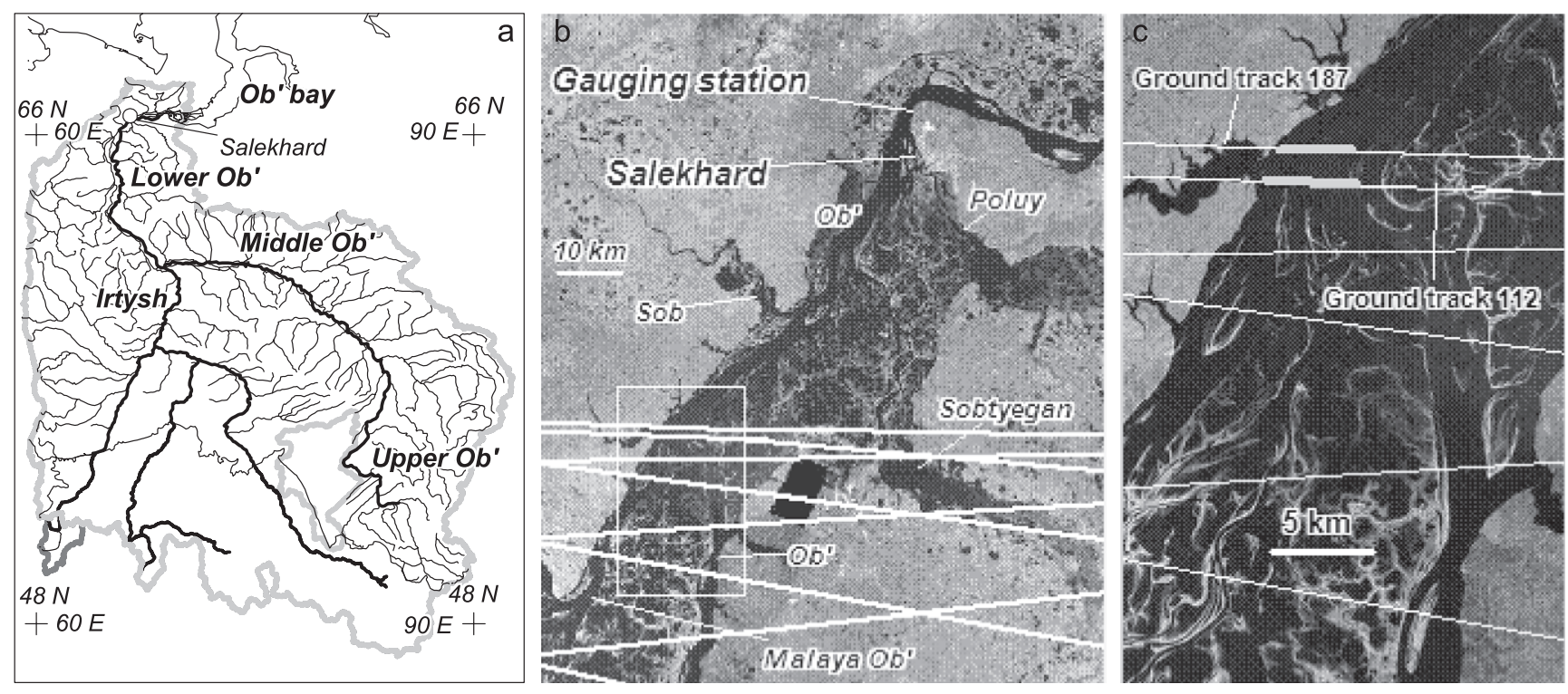

Fig. 1. (a) Ob' watershed and river network. (b) Landsat Thematic Mapper image with superimposed T/P ground tracks (white lines) near the Salekhard gauging station. (c) Zoom on the white rectangle shown in (b), thick gray lines represent the intersections of the T/P ground tracks with the main Ob' channel. 


\section{Data}

\subsection{In situ data}

To establish the relations between satellite and in situ measurements, we used the river level and discharge measured at the Salekhard station (last observation point before the $\mathrm{Ob}$ ' enters the $\mathrm{Ob}$ ' bay and the Kara sea), one of the few gauging stations for which appropriate data is available. Mean monthly values were obtained from RArcticNet web site (R-ArcticNet, 2003) from 1992 to 2001 and complemented by daily river level and discharge data (R. Holmes, personal communication) after January 2000 acquired from the ArcticRIMS web site (ArcticRIMS, 2003). Additional data on daily level and discharge observations for 1970 were acquired from (State Water Cadaster, 1971).

\subsection{Satellite altimetry data}

A satellite radar altimeter performs vertical range measurements between the satellite and the reflecting water surface. The difference between the satellite altitude above a reference surface (either a conventional ellipsoid or a model geoid surface) determined through precise orbit computation, and the distance from the satellite to the water provides a measurement of the water level above the reference surface (altimeter range). Placed onto a repeat orbit, the satellite altimeter overflies a given region at regular time intervals (called the orbital cycle). The TOPEX/Poseidon radar altimeter is on a 10-day repeat orbit, well suited to monitor rivers discharge variations, while the 35-day repeat orbit of the ERS altimeters is too coarse especially for Arctic rivers who are subject to intense increase in discharge over 1- or 2-month periods in the spring when snow melts.

The TOPEX/Poseidon (T/P) altimetry data were obtained from the Geophysical Data Records (GDR-Ms) available from the Archiving Validation and Interpretation of Satellite Data in Oceanography (AVISO) data center at the Centre National d'Etudes Spatiales (CNES) (AVISO, 1996) and consist of range values from radar echoes at $1 / 10 \mathrm{~s}$ and averaged values at $1 \mathrm{~s}$ interval, corresponding to along-track ground spacing of $596 \mathrm{~m}$ and $5.96 \mathrm{~km}$, respectively. The inclination of the T/P orbit $\left(66^{\circ}\right)$ allows for most of the $\mathrm{Ob}$ ' basin to be sampled by numerous intersections between satellite ground tracks and rivers at a 10-day resolution (the duration of an orbital cycle). Ten years of satellite altimetry data have been analysed covering the period from September 1992 to August 2002 (cycles 1 through 365), before T/P was moved to a new orbit. Environmental and geophysical corrections of the altimeter range measurements relevant to the $\mathrm{Ob}^{\prime}$ basin have been applied. The corrections applied include ionospheric, dry tropospheric, solid Earth tide corrections and correction for the satellite's centre of gravity. We neglect, on the other hand, corrections specific to open ocean environments such as ocean and pole tides, ocean tide loading, inverted barometer effect and sea state bias. The wet tropospheric correction, normally derived from the onboard TOPEX Microwave Radiometer (TMR) over oceans, is not available over land in the GDR-Ms. The TMR instrument has a large footprint (up to $43.4 \mathrm{~km}$ in diameter for the $18 \mathrm{GHz}$ channel). When the satellite flies over rivers, the TMR footprint almost always includes surrounding lands, which contaminates the measurements and makes atmospheric water vapor measurement unreliable. However, over land, the wet tropospheric correction can be modelled using meteorological operational analyses and it has been computed for the whole $\mathrm{T} / \mathrm{P}$ mission by Mercier (2003) using air temperature and specific humidity fields from National Centers for Environmental Predictions (NCEP) meteorological fields. The water heights have been referred to the JGM3/OSU95A geoid surface (AVISO, 1996).

\section{4. $\mathrm{Ob}^{\prime}$ river level and discharge from Topex/Poseidon}

\subsection{Data selection}

A mountainous topography may lead the altimeter to lock off completely, requiring some time to lock on again; even over water and for narrow rivers the instrument may deliver no reliable measurement at all. In other cases, the instrument could remain locked on water while the satellite is well ahead of the water body, since the reflected signal on water has more power than the reflected signal on land. This may cause a geometric error that could reach several meters for some regions.

In order to minimise potential contamination of the T/P signal by land reflections, and at the same time to retain a sufficiently large number of altimeter measurements on water, we performed a geographical selection of the data. We used GeoCover ${ }^{\mathrm{TM}}$ Landsat Thematic Mapper orthorectified mosaics with $28.5 \mathrm{~m}$ pixel size available from the MrSID Image Server (MrSID web site, 2003) to select with a high spatial resolution the most appropriate satellite tracks-river intersections. The width of the Ob' River in this region changes seasonally from 2 to $20 \mathrm{~km}$ depending on the phase of the hydrological regime. To get consistent measurements in various phases of the water regime, we selected only those parts of the T/P ground tracks that cover the main channel of the $\mathrm{Ob}$ ' river system (Fig. 1c). This rigorous selection was made using the $1 / 10 \mathrm{~s}$ level measurements.

Over continents, radar echoes are affected by topography, vegetation, ice and snow cover. As a consequence, the waveform (i.e. the power distribution in time of the radar echo) may not have the simple broad-peaked shape typical of ocean surfaces, but can be complex and multi-peaked (Berry, 2003; Birkett, 1998). The existing $\mathrm{T} / \mathrm{P}$ ocean retracking algorithm is not designed to process 
such signals and this affects the precision of determination of the altimetric height. For the relatively flat lower $\mathrm{Ob}$ ' region near Salekhard, the presence of ice and snow (on land and on river ice) perturbs the altimeter measurements, which are strongly attenuated by their presence (Kouraev et al., 2003a; Papa et al., 2002). The characteristics of the radar echo over ice and snow depend on the volume scattering effect of the media and the two-way attenuation of the return signal.

Snow over land in this region is not very deep (the total annual amount of solid precipitation varies between 100 and $200 \mathrm{~mm}$ ) (World Atlas of Snow and Ice Resources, 1997) and the precise geographic selection of the $\mathrm{T} / \mathrm{P}$ data reduces the potential influence of snow-covered land on the altimetric signal. The ice cover, which is present for more than half of the year, influences significantly the radar waveform and backscatter values not only in periods of stable ice cover, but also during ice formation and break-up (Kouraev et al., 2003b). A new retracking algorithms adapted to various terrain such as open and ice-covered rivers will increase the reliability of river level estimates from altimetry observations (Berry, 2003). Until new algorithms better adapted to land become available, we use the standard GDRs that offer useful information on land waters (Birkett, 1998).

Due to the $66^{\circ} \mathrm{N}$ inclination of the satellite orbit, the closest satellite pass to the Salekhard station is located approximately $65 \mathrm{~km}$ south of the station (Fig. 1). For the lower $\mathrm{Ob}$ ' basin, the $\mathrm{T} / \mathrm{P}$ measurements along the tracks close to Salekhard provide reliable water level $(H)$ time series that are used to estimate water discharge $(Q)$ from the rating curve between $H$ and $Q$. We used the in situ daily discharge data acquired during 2000-2002 at the Salekhard gauging station (ArcticRIMS, 2003) and the data from the two T/P ground tracks (112 and 187), nearest to Salekhard. The distance between the gauging station and these $\mathrm{T} / \mathrm{P}$ tracks is about $65-70 \mathrm{~km}$, while the distance between the two satellite tracks is $2.5 \mathrm{~km}$. The two chosen satellite tracks sample the $\mathrm{Ob}^{\prime}$ in the relatively narrow area just after the confluence of the two main branches of the $\mathrm{Ob}^{\prime}$ in its lower part-Ob' and Small Ob' (see Fig. 1b). Between the satellite tracks and Salekhard, there are only three small rivers - Sob', Sob'yegan and Poluy. The largest river is Poluy with an annual discharge of $4.1 \mathrm{~km}^{3} /$ year (ArcticRIMS, 2003) representing about $1 \%$ of the $\mathrm{Ob}^{\prime}$ discharge at Salekhard, so the influence of lateral river inflow between the chosen T/P tracks and Salekhard can be neglected for this study.

The $\mathrm{Ob}$ ' valley near the tracks 112 and 187 has several secondary channels and vast flood plains in its eastern part. By mid-May, the plain is rapidly flooded and then the water gradually returns into the main channel, thus increasing the flood period. Numerous old channels, lakes and bogs have water level regimes that differ from the main channel. As a result, the satellite time series of water level are noisy and a precise geographical selection is necessary to establish a robust $H-Q$ relation. To eliminate the noise, we only considered the data over the main $\mathrm{Ob}$ ' channel, which is about $3 \mathrm{~km}$ wide (see Fig. 1). Next, we averaged the selected $1 / 10 \mathrm{~s}$ level measurements and constructed the T/P water level time series over the orbital cycle (10-day interval). At the beginning of the flood, the number of $\mathrm{T} / \mathrm{P}$ data in the GDR-Ms dramatically drops, mostly because the onboard automatic tracker algorithm experiences difficulties in processing the return waveform significantly modified by the ice cover break-up. We consider the relation $H-Q$ for each of the two tracks and establish an algorithm to calculate the discharge from the T/P level time series.

\subsection{River level}

The water levels at Salekhard and along the T/P tracks vary synchronously and the time series are dominated by the annual cycle. The superposition of the two series (Fig. 2),

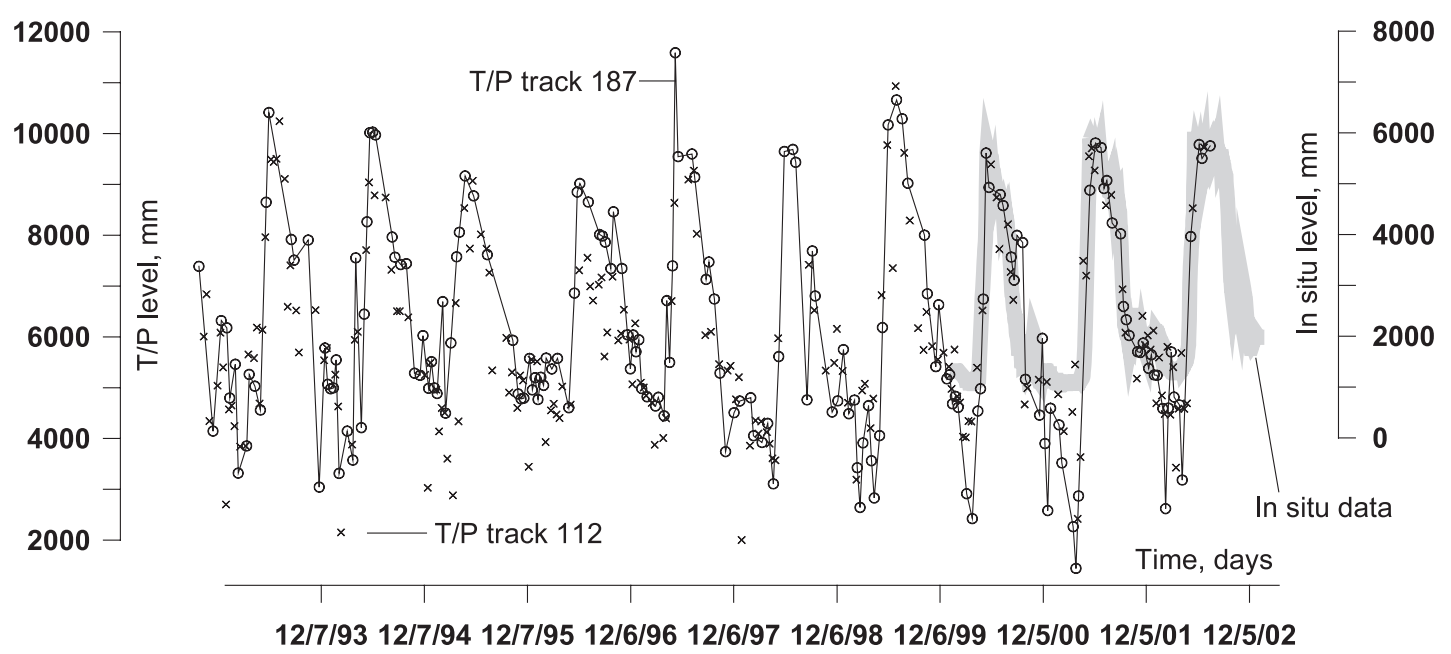

Fig. 2. Time series of T/P water level for tracks 187 and 112 (referred to the JGM3/OSU95A geoid surface), and in situ data at Salekhard (referred to the gauging station datum) overlaid on T/P data. 
altimeter-derived data referred to the geoid and in situ measurements refer to gauging station datum, shows that during the open water period the timing and the amplitude of the river level variability are very close. The standard deviation of the $1 / 10 \mathrm{~s}$ level measurements available for each cycle at ground track 187 changes from $40 \mathrm{~cm}$ during spring flood to $23 \mathrm{~cm}$ during water level decrease in late summer early fall. With the presence of ice, the standard deviation increases again up to $30 \mathrm{~cm}$. During winter, when the river is ice-covered, the T/P level series become unstable and have lower values (up to 2-3 m) compared to the level observed at Salekhard.

There is a time lag in river level between Salekhard and the satellite tracks and this lag varies for the different hydrological phases. As the flood wave and related ice break-up propagates northward, the beginning of the spring flood at the T/P tracks is about 20 days earlier. When the ice has gone, the flood wave moves freely and the time lag for the highest water levels is reduced to less than 5 days. In autumn, the formation of young ice often causes temporal water level increase related to the constriction of the river channel cross section. As the formation of the ice moves southward, first small peaks are observed at Salekhard, and then at the satellite tracks, with time lag of 25-30 days.

\subsection{Level-discharge relation}

The water discharge is functionally related to the water level at the given location. This relation, called the "stagedischarge rating curve" (or simply "rating curve") is determined from simultaneous measurements of water level and corresponding discharge and can be simple or complex. The simplest forms of the rating curves are observed in the cases of stable channels with steady flow. The rating typically follows the power law given by the equation (Ranz et al., 1982)

$Q=C(H-e)^{b}$

where $Q$ is the discharge, $H$ the water level, and $C, e$ and $b$ are coefficients. A polynomial function can be used to fit the curves. Amongst the factors controlling the ratio are the shape of the riverbed, scour of channel, rapid changes of flow (unsteady flow), changes in hydraulic roughness (seasonal development of water vegetation, debris, sediment redeposition, ice), backwater effect, etc. Usually, the stage-discharge rating for a given point consists of the whole family of curves corresponding to different periods when the flow is assumed to be steady. Very often, the simple temporal analysis of the water level and discharge series already provides the possibility to discriminate the main periods of quasi-steady flow. Further detailed studies specific for each river are directed towards assessing the main factors responsible for the unsteadiness and for adjusting the rating curves according to these factors.

For rivers with vast flood plains like the $\mathrm{Ob}$, the rating curve consists of several branches corresponding to the different hydraulic conditions (or hydrological phases) (Bykov \& Vasiliev, 1973). The $H-Q$ diagram based on the daily water level and discharge in situ data for 1970 and for 2001 (Fig. 3a) shows these branches. The good relation between the data for 1970 and 2001 shows that for the last 30 years there were no significant changes in the factors that could have affect $H-Q$ relation at the Salekhard station.

In order to reconstruct the discharge at Salekhard from the $\mathrm{T} / \mathrm{P}$ data, we directly constructed the rating curves between the T/P-derived river level $(H)$ at the satellite tracks and the river discharge at Salekhard $(Q)$ (Fig. 3b). This a

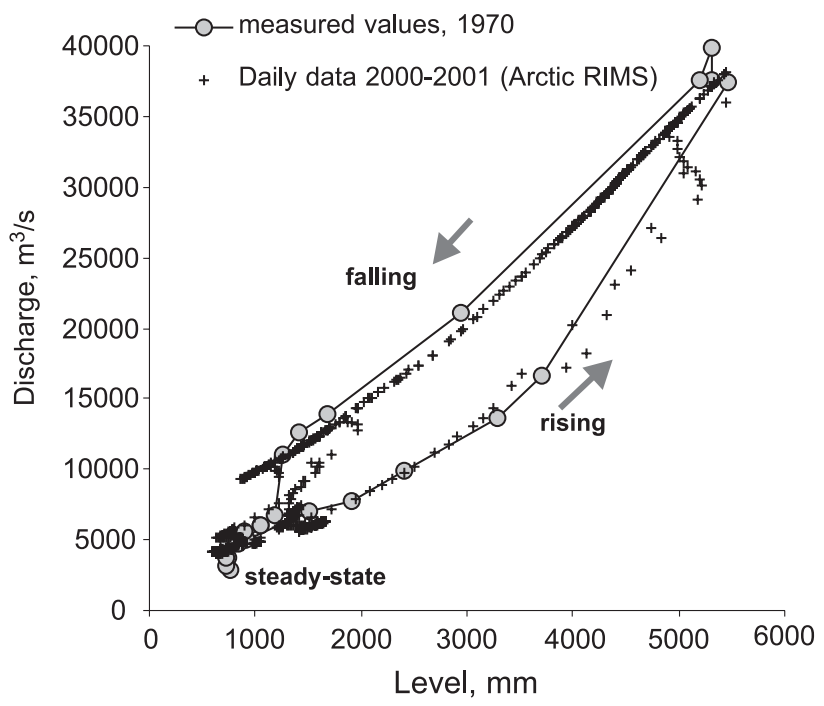

b

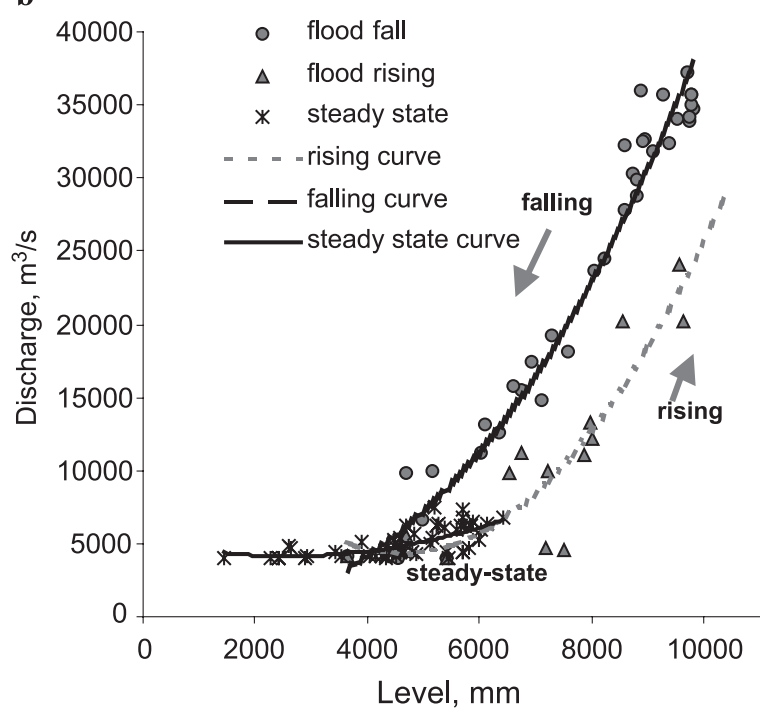

Fig. 3. H-Q relation as a function of the hydrological phases: (a) in situ data (1970 and 2001); (b) T/P data for 2000-2002. 


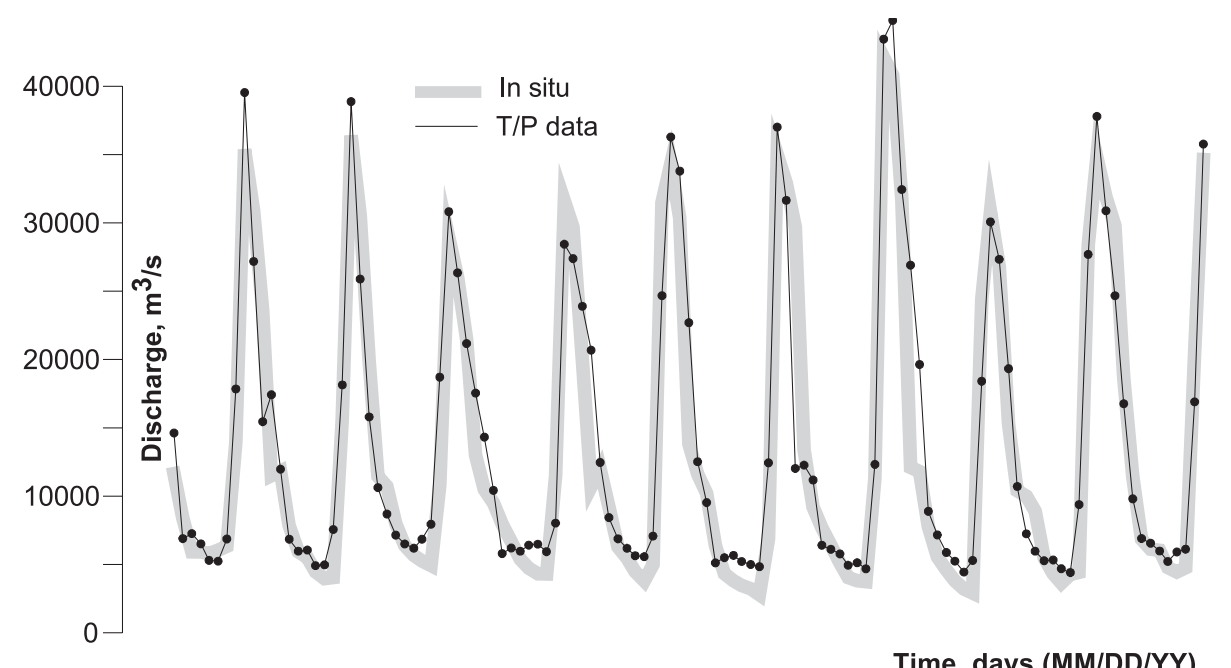

Time, days (MM/DD/YY)

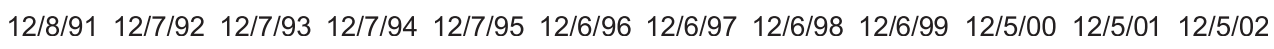

Fig. 4. Mean monthly water flow $\left(\mathrm{m}^{3} / \mathrm{s}\right)$ at Salekhard from in situ and satellite-derived data (ground track 187).

direct calculation significantly reduces the potential errors, compared to other possible approach which consist of using the T/P-derived river level to reconstruct the river level at Salekhard and then applying the various existing rating curves for Salerkhard gauging station to calculate the discharge.

The data have been divided into three subperiods: flood rising, flood falling and a winter period of quasi-steady conditions. For 2000-2002 when we have access to daily discharge data, we have constructed the diagrams $Q=f\left(H_{\mathrm{T} / \mathrm{P}}\right)$ and approximated the points for each of the three periods by polynomial functions (Fig. 3b). Then, we have calculated $Q$ for each T/P crossing for 1992-2002 and interpolated the data to calculate the $Q$ values for every day of the year in order to compute monthly $Q$ values and compare them to the RIMS data. The number of valid T/P data varies for each track, some years there are very few data for 1-2 months (for example, May-July 1998 for track 112 and JulyAugust 1993-1995 for track 187), which reduces the accuracy of the river discharge estimations at the monthly and annual scale.

\subsection{Comparison between observed (in situ) and TOPEX/ Poseidon-based river discharge}

The calculation of daily discharge values is most successful when using data for the ground track 187 (track with the most complete data set). Comparison of T/Pderived discharge and in situ data for Salekhard is shown in Fig. 4 for the overlapping period 2000-2002, the average error (median value) is $675 \mathrm{~m}^{3} / \mathrm{s}$ or $8 \%$. Satellite estimates compared to in situ data give an $r^{2}$ of 0.99 (number of observations $n=54$ ). This regression gave a slope 0.99 and intercept of 265 . No wonder, the maximal errors in calculating daily errors are observed during the most complicated hydrological phase-ice break-up and the beginning of spring flood. Water movement in the riverbed at this time is far from regular and thus

Discharge anomaly, $\mathrm{m} 3 / \mathrm{s}$

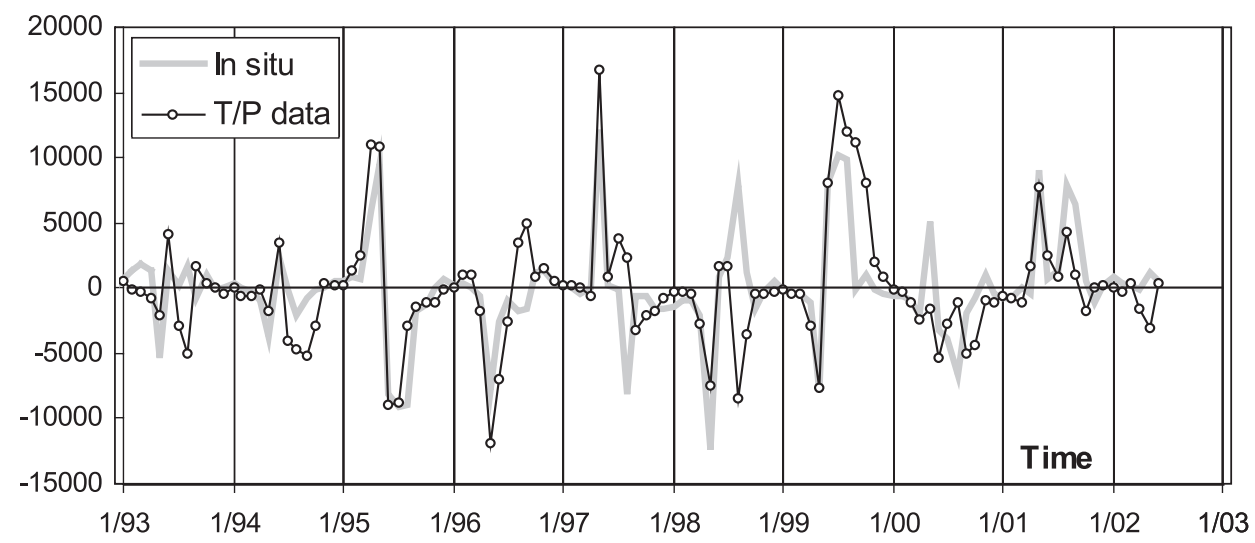

Fig. 5. Mean monthly anomalies (excluding seasonal variability) of water flow $\left(\mathrm{m}^{3} / \mathrm{s}\right)$ at Salekhard, in situ and satellite-derived data (track 187). 
calculation of $Q$ is complicated by factors such as backwater and overbank flow. For these periods it is necessary to introduce transition coefficients. However, this requires additional information such as shape of the riverbed and valley and definition of levels at which water starts to cover the floodplain.

The errors on the computed daily discharge from T/P data are well within the range of errors acceptable for the establishment of stable multi-annual $H-Q$ relation based on the in situ data of the river level and discharge according to the standards (Guidebook for the hydrometeorological stations and posts, 1958). These standards define acceptable errors as $\pm 12 \%$ of discharge for the lower part of the rating curve (first $20 \%$ of the highest water level amplitude) and $\pm 8-10 \%$ for the rest.

A comparison of monthly mean discharge values from in situ data and from T/P estimates for track 187 (see Fig. 5) shows a very good agreement. Satellite altimetry allows to calculate monthly values, which are important for climate and ecological numerical modelling, with mean (median values) absolute error of $1440 \mathrm{~m}^{3} / \mathrm{s}(11 \%$ of annual discharge) and relative error of $17 \%$. Maximal errors are observed during ice break-up and also during period of sharp decrease of water level (August-September) when overbank flow ends and water returns to the main river channel.

We also suppose that during the water depletion period in August-October there is a temporary water level rise in the region of ground track 187 , which should be represented by yet another relation $Q-H_{\mathrm{T} / \mathrm{P}}$, but the scarcity of valid $\mathrm{T} / \mathrm{P}$ data for this period does not allow to fully parameterise this process. In conditions of quasi-constant water discharge, observed during winter, errors related to the uncertainty of $\mathrm{T} / \mathrm{P}$ water level estimation during ice period do not result in significant errors on the $Q$ calculation.

A comparison of the annual discharges from the T/P water levels with the in situ data (Table 1) shows that the errors between the two estimates are about $400 \mathrm{~m}^{3} / \mathrm{s}$ or $3 \%$ (median values) of mean annual river discharge. The large errors of annual flow estimations noted in 1995 and 1999 years are caused by the interpolation of discharge estimations when T/P data were not available. In this case, when the T/P data for ground track 187 are missing for more than five consecutive cycles (1.5 month), using the monthly discharge data calculated from T/P observations for ground track 112 increases the accuracy. We have implemented this approach for 1995, 1997 and 1999 (see Table 1), reducing the errors to $180 \mathrm{~m}^{3} / \mathrm{s}$ or $1 \%$ of the annual value.

The comparison of monthly satellite and in situ river discharge anomalies for 1992-2001 shows a good agreement in the timing of the various stages of the hydrological regime and in the interannual variability caused by early or late spring flood (resulting in the shift of the observed maximal discharge timing: positive anomalies followed by negative ones for early flood and the inverse for late flood) (Fig. 5). The discrepancies observed in 1998 are due to missing $\mathrm{T} / \mathrm{P}$ observations.

\section{Conclusions}

In this study, we compare in situ and satellite-derived estimations of the $\mathrm{Ob}$ ' discharge at Salekhard and show that the $T / P$ river level data can successfully be used for hydrological studies of seasonally ice-covered Arctic rivers. The accuracy of the $Q$ estimation is good enough to estimate the daily discharges and the annual water flow with an average error of $8 \%$ and $1-3 \%$, correspondingly. For the mean monthly discharges, the average errors increase up to $17 \%$, mostly due to the scarcity of valid $\mathrm{T} / \mathrm{P}$ observations during some periods and $Q$ overestimation during the water depletion period in August-October. The introduction of new retracking algorithms for computing the river level will significantly increase the accuracy of the discharge estimates. The approach discussed in this article is still limited to rivers that are several kilometres wide because of the current satellite altimeters resolution. With a new generation of radar altimeters dedicated to continental hydrology, rivers with width on the order of $100 \mathrm{~m}$ could be monitored from space.

T/P-derived discharge estimates and other hydrological parameters, such as dates of the beginning and the end of spring flood, in combination with other hydrometeorological data (air temperatures, precipitation, snow cover extent and volume, etc.) will provide valuable information for studies of water budget and its variability for the whole $\mathrm{Ob}$ ' watershed or selected parts and is the aim of future research.

Hydrologic sensitivity is one of the main control variables that determines the future response of the Arctic regions to large-scale climate changes. It is also one of the largest sources of uncertainty in predicting this response, because hydrologic sensitivity is, at the moment, poorly constrained by observations. Using the satellite altimetric

Table 1

Mean annual values of river discharge (in $\left.\mathrm{m}^{3} / \mathrm{s}\right)$ at Salekhard from in situ and satellite data, and errors (\%) of estimation

\begin{tabular}{|c|c|c|c|c|c|c|c|c|c|}
\hline $\begin{array}{l}\text { Discharge }\left(\mathrm{m}^{3} / \mathrm{s}\right) \text { and } \\
\text { associated error }\end{array}$ & 1993 & 1994 & 1995 & 1996 & 1997 & 1998 & 1999 & 2000 & 2001 \\
\hline In situ data & 13,750 & 13,070 & 12,560 & 12,490 & 13,440 & 12,870 & 15,000 & 12,220 & 15,390 \\
\hline Track 187 & 13,840 & 12,930 & 14,360 & 13,420 & 14,620 & 12,490 & 18,010 & 12,100 & 15,410 \\
\hline Error, \% & -1 & 1 & -14 & -7 & -9 & 3 & -20 & 1 & 0 \\
\hline Tracks 187 and 112 & 13,850 & 12,960 & 13,260 & 13,450 & 13,620 & 12,510 & 15,907 & 12,150 & 15,470 \\
\hline Error, \% & -1 & 1 & -6 & -8 & -1 & 3 & -6 & 1 & -1 \\
\hline
\end{tabular}


technique described in this paper for monitoring the main Arctic rivers would help constrain observations in the Arctic region. Altimeter estimates could complement in situ river discharge measurements for a global monitoring service of the environment. The contribution of spatial observations to continental hydrology is likely to develop increasingly in the near future: besides the new radar altimeters on board Jason and ENVISAT, the gravimetric mission GRACE will soon provide the water mass spatio-temporal variations at global and regional scale of $200 \mathrm{~km}$, offering another validation source for the new global hydrologic models that are currently developed.

\section{Acknowledgements}

We are grateful to Dr. Robert Max Holmes from the Ecosystems Center, Marine Biological Laboratory in Woods Hole, MA, for kindly sending us the monthly Ob' River discharge data at Salekhard, and to Franck Mercier for kindly providing wet tropospheric corrections data. This work was partly supported by the AICSEX (Arctic Ice Cover Simulation Experiment) Project of the 5th EU Framework program, and the ACI Observation de la Terre from the French Ministry of Research.

\section{References}

ArcticRIMS. (2003).-A Regional, Integrated Hydrological Monitoring System for the Pan-Arctic Land Mass http://www.watsys.sr.unh.edu/ arctic/RIMS/.

AVISO User Handbook. (1996). Merged TOPEX/Poseidon Products (GDR-Ms), AVI-NT-02-101-CN, Edition 3.0.

Berry, P. A. M. (2003). Global river and lake monitoring from multimission altimetry: capability and potential. The Abstracts of the Workshop Hydrology from Space, 29 September-1 October 2003, Toulouse, France.

Birkett, C. (1995). The contribution of TOPEX/POSEIDON to the global monitoring of climatically sensitive lakes. Journal of Geophysical Research, 100, 25179-25204.

Birkett, C. (1998). The contribution of TOPEX NASA radar altimeter to the global monitoring of large rivers and wetlands. Water Resources Research, 34, 1223-1239.

Bjerklie, D. M., Dingman, S. L., Vorosmarty, C. J., Bolster, C. H., \& Congalton, R. G. (2003, 25 July). Evaluating the potential for measuring river discharge from space. Journal of Hydrology, 278(14), $17-38$.

Broecker, W. S. (1997). Thermohaline circulation, the Achilles Heel of our climate system: will man-made $\mathrm{CO}_{2}$ upset the current balance? Science, 278,1582

Bykov, V., \& Vasiliev, A. (1973). Hydrometry. Leningrad, Russia: Hydrometeoizdat. 448 pp., in Russian. de Olivera Campos, Ilce, et al. (2001). Temporal variations of river basin water from TOPEX/Poseidon satellite altimetry. Application to the Amazon basin. Comptes Rendus de l'Académie des Sciences, Serie II, Sciences de la Terre et des planétes, 333, 1-11.

Guidebook for the hydrometeorological stations and postsIssue 6. (1958). Part III, "Compilation and preparation of the hydrological yearbook". Main Direction of Hydrometeorological Service of the Soviet of the Ministres of the USSR, Hydrometeorological publishing, Leningrad, $291 \mathrm{pp}$.

IPCC (Intergovernmental Panel on Climate Change). (2001). Climate Change 2001: The Scientific Basis. Contribution of Working Group to the Third Assessment Report of the PCC. In J.T. Houghton, et al. (Eds.) Cambridge Univ. Press, Cambridge.

Kouraev, A. V., Papa, F., Buharizin, P. I, Cazenave, A., Crétaux, J. -F., Dozortseva, J., et al. (2003). Ice cover variability in the Caspian and Aral seas from active and passive satellite microwave data. Polar Research, 22(1), 43-50.

Kouraev, A. V., Mognard, N. M., Zakharova, A., LeToan, T., Grippa, M., \& Cazenave, A. (2003). Snow cover in the Ob' river watershed and its role in the formation of river discharge. The Abstracts of the workshop Hydrology from Space, 29 September-1 October 2003, Toulouse, France.

Maheu, C., Cazenave, A., \& Mechoso, C. R. (2003). Water level fluctuation in La Plata basin (South America) from TOPEX/Poseidon satellite altimetry. Geophysical Research Letter, 30, 3.

Mercier, F. (2001). Altimétrie spatiale sur les eaux continentales: Apport des missions TOPEX/POSEIDON et ERS-1 and 2 á l'etude des lacs. mers intérieures et bassins fluviaux., $\mathrm{PhD}$ thesis. Université Paul Sabatier.

Mercier, F. (2003, April). Satellite altimetry over non-ocean areas: An improved wet tropospheric correction from meteorological models. EGS-AGU-EUG Joint Assembly. France: Nice.

MrSID Image Server. (2003). NASA Earth Science Application Directorate, https://www.zulu.ssc.nasa.gov/mrsid/.

Papa, F., Legresy, B., Mognard, N., Josberger, E. G., \& Remy, F. (2002). Estimating terrestrial snow depth with the TOPEX/Poseidon altimeter and radiometer. IEEE Transactions on Geoscience and Remote Sensing, 40, 2162-2169.

Peterson, B. J., Holmes, R. M., Mc Clelland, J. W., Vörö smarty, C. J., Lammers, R. B., Shiklomanov, A. I., et al. (2002). Increasing river discharge to the Arctic ocean. Science, 298, 2171-2173.

Rahmstorf, S. (1995). Bifurcations of the Atlantic thermohaline circulation in response to changes in the hydrological cycle. Nature, $378,145-149$.

R-ArcticNet. (2003). v. 2.0-A Regional, Electronic, Hydrographic Data Network For the Arctic Region, http://www.r-arcticnet.sr.unh.edu/.

Ranz, S. E., et al. (1982). Measurement and computation of streamflow: Volume 2. Computation of discharge. Water Supply Paper 2175, U.S. Geological Survey, pp. 285-631.

Russia: River basins. (1999). Ekaterinbourg, 520 pp. In Russian.

Shiklomanov, A. I., Lammers, R. B., \& Vorosmarty, C. J. (2002). Widespread decline in hydrological monitoring threatens Pan-Arctic research. EOS Transactions AGU, 83, 13-16.

State Water Cadaster. (1971). Annual observations data. Ob' river basin. (in Russian).

World Atlas of Snow and Ice Resources. Moscow, Russia: Russian Academy of Sciences. 